\title{
Changes in the Value Added Tax as the Tool against the Global Crisis"
}

\author{
Alena DUGOVÁ*
}

The global economic crisis has requested inter alia couple of state intervention particularly in taxation. Value added tax ("VAT") and further general indirect taxes are widespread throughout the world and actually the VAT is the tax where the tax frauds are committed frequently, therefore, majority of the states introduced various proceedings in field of indirect taxation as the tool against the global economic crisis. The states usually increased the VAT rates and rely on the increase in the public revenues. On the other hand, for increasing of the public revenues states launched some efficient proceedings against the tax frauds which are committed in area of VAT in huge amounts.

This paper deals with the changes in VAT made during years 20082013, i.e. from the beginning of the global economic crisis and further years of the economic slowdown. The first part of the paper describes the changes in VAT rates in the states of the European Union ("EU") where the VAT is harmonized by the EU law. The second part is the overview of the anti-fraud tools introduced by the various states. Some of the tools are very simple but some of them are quite legally complex.

The impact of the global economic crisis confirms the statistical data. This fact is evidenced among others in statistical book of Eurostat where is stated that the crisis together with measures of fiscal policy adopted in the countries has a strong impact on the level and composition of tax revenue in 2009-2011, although the first effects had already become visible in 2008 (EC, 2013a). The data also show decreasing of the direct taxes during these years.

\footnotetext{
\# This article has been elaborated as one of the outcomes of research project The Effect of Tax and Expenditure Instruments on Macroeconomic and Microeconomic Efficiency which id granted by Internal Grant Agency of University of Economics in Prague under registered number F1/30/2010.

Mgr. Ing. Alena Dugová - Ph.D. student; Department of Public Finance, Faculty of Finance and Accounting, University of Economics, Prague, W. Churchill Sq. 4, 13067 Prague 3, Czech Republic; <alena.dugova@ @entrum.cz>.
} 
Results of this research might be useful as the inspiration for other states in global economy to change the VAT rates or to introduce some anti-fraud tools.

\section{Changes in the VAT rates}

Change of the VAT rates is relatively simple step of the government, and therefore, some states increased the VAT rates as the reaction on the economic crisis because they wanted to increase the revenues in public budgets. Some economists, however, point out that the increase in VAT rates does not have to lead to increase in the public revenues as the people start to limit their spending. Moreover, some authors (Kubátová, 2010) are opinion that with the increase of the VAT rates, the suppliers increase the effort for the tax evasion. If state wants to change the VAT rates, the limits stated by VAT Directive must be fulfilled. The standard rate cannot be lower than $15 \%$ and the reduced rate cannot be lower than $5 \%$ and state can have 2 reduced rates, however, some exceptions (e.g. super reduced and parking rates) from the rules are granted. However, there is no maximum high of the VAT rate stated in the EU VAT Directive. Therefore, states are not limited in the determination of the VAT rates for their increasing.

Another way of VAT changes is that EU generally plans to submit a proposal at the end of 2013 to reduce the goods and services falling under the reduced VAT rate. Other experts (Copenhagen Economics, 2007) suggest that VAT should in general be levied to the extent possible on a broad base minimising revenue losses from exemptions and reduced rates. However, VAT exemption and reduced rates differ from country to country. The European Commission and OECD (2013) recommend applying a single uniform rate to all goods and services subject to VAT as the single uniform rates make the system more transparent and reduce the room for tax frauds. The impacts of the single VAT rate which was already proposed, not approved, but still planned for the Czech economy was estimated (Dušek - Jánský, 2011) as the decreasing of the deficit of the public budgets about CZK 20 billion in the long term. The uniform VAT rate was among others subject of the study in Denmark (Gordon Nielsen, 1997) where was concluded that Denmark's high uniform VAT rate of $25 \%$ could reduce the real costs of tax evasion activity by relying even more on VAT.

Of course the increase in the VAT rates is not connected only with the economic crisis, but politically such reasoning is viable. Actually, VAT 
is collected easily and efficiently and brings the considerable revenues to the state budget. Moreover, the increases in VAT rate is also reasoned that that the changes in the indirect taxes do not have such impact on the domestic economy as may represent the changes in the direct income taxes. This opinion was confirmed inter alia in the economic study (Buus, 2012) where was validated that the replacement of taxation of factors of production by increasing the VAT would have a positive impact on the product, employment and wages, and in addition would help reduce the excessive tax burden borne by the Czech tax payers. Moreover, as the VAT is included in the prices paid by the final customers, the change is not so visible for the customers, however, the change in the direct taxation is more visible and, therefore, more sensitive.

Between years 2008-2013 the VAT rates were changed in the $20 \mathrm{EU}$ member states (i.e. Bulgaria, Czech Republic, Estonia, Greece, Spain, France, Ireland, Italy, Cyprus, Latvia, Lithuania, Hungary, Malta, Netherlands, Poland, Portugal, Romania, Slovakia, Finland, United Kingdom). The most common change was the increase for 1 percentage point (i.e. Czech Republic, Greece, Spain, Italy, Cyprus, Latvia, Lithuania, Poland, Portugal, Slovakia, Finland), however, some stated increased the VAT rates more rapidly even for 5 percentage points (i.e. Latvia, Hungary, Romania). Therefore, the obvious trend in the EU is the increase of the VAT rates. In some countries, it was publically presented that the changes in VAT rates are only temporary. For example in the Czech Republic, the lawmakers explained the changes in VAT rates in 2013 for 1 percentage point in the explanatory report to the VAT act as a way how to increase tax revenues in state budged especially due to the structural deficit. Moreover, it was explained that the increased rates of 1percentage point should be valid only for 3 years and then there should most probably be a flat rate of $17.5 \%$ (this is however uncertain). For example, in Slovakia the VAT rate change in standard rate in 2011 for 1 percentage point was presented as the temporary increase and that the expiry of the standard VAT rate $20 \%$ is determined by the height of the general government deficit and if the European statistical office Eurostat announces that the current deficit of the general government of Slovakia is less than 3\% then the increase in the standard VAT rate will apply only until the end of the calendar year in which it was current deficit less than 3\% announced. However, this reasoning might be only for approval of the changes, but the real decreasing of the VAT rates should not be approved in future. The concrete changes are stated in the Table 1: Changes in the VAT rates (2008-2013). Based on the opinion of 
EU for future, the tax payers can await further increasing and emphasis on the indirect taxation including the increasing of the VAT rates or in the form of the introduction of the new indirect taxes (e.g. the tax of the financial transactions which is already approved).

Tab. 1: Changes in VAT rates (2008-2013)

\begin{tabular}{|c|c|c|c|c|c|}
\hline $\begin{array}{c}\text { Member } \\
\text { state }\end{array}$ & From & \begin{tabular}{|c|} 
Type of \\
VAT rate
\end{tabular} & From & To & $\begin{array}{l}\text { Percentage } \\
\text { points }\end{array}$ \\
\hline Bulgaria & 1. 4. 2011 & reduced & 7 & 9 & $2 \%$ \\
\hline \multirow{5}{*}{$\begin{array}{l}\text { Czech } \\
\text { Republic }\end{array}$} & 1.1 .2010 & reduced & 9 & 10 & $1 \%$ \\
\hline & & standard & 19 & 20 & $1 \%$ \\
\hline & 1. 1.2012 & reduced & 10 & 14 & $4 \%$ \\
\hline & 1.1.2013 & reduced & 14 & 15 & $1 \%$ \\
\hline & & standard & 20 & 21 & $1 \%$ \\
\hline \multirow{2}{*}{ Cyprus } & 1.3 .2012 & \begin{tabular}{|l|} 
standard \\
\end{tabular} & 15 & 17 & $2 \%$ \\
\hline & 14. 1.2013 & standard & 17 & 18 & $1 \%$ \\
\hline \multirow{2}{*}{ Estonia } & 1. 1.2009 & reduced & 5 & 9 & $4 \%$ \\
\hline & 1.7.2009 & standard & 18 & 20 & $2 \%$ \\
\hline \multirow{6}{*}{ Finland } & 1.7 .2010 & reduced & 8 & 9 & $1 \%$ \\
\hline & & reduced & 12 & 13 & $1 \%$ \\
\hline & & standard & 22 & 23 & $1 \%$ \\
\hline & 1.1 .2013 & reduced & 9 & 10 & $1 \%$ \\
\hline & & reduced & 13 & 14 & $1 \%$ \\
\hline & & standard & 23 & 24 & $1 \%$ \\
\hline \multirow{8}{*}{ Greece } & 15.3. 2010 & reduced & 4.5 & 5 & $0.5 \%$ \\
\hline & & reduced & 9 & 10 & $1 \%$ \\
\hline & & standard & 19 & 21 & $2 \%$ \\
\hline & 1.7 .2010 & reduced & 5 & 5.5 & $0.5 \%$ \\
\hline & & reduced & 10 & 11 & $1 \%$ \\
\hline & & standard & 21 & 23 & $2 \%$ \\
\hline & 1.1.2011 & reduced & 5.5 & 6.5 & $1 \%$ \\
\hline & & reduced & 11 & 13 & $2 \%$ \\
\hline France & 1. 1.2012 & reduced & 5.5 & 7 & $1.5 \%$ \\
\hline \multirow{3}{*}{ Hungary } & 1.7 .2009 & reduced & 5 & 18 & $13 \%$ \\
\hline & & standard & 20 & 25 & $5 \%$ \\
\hline & 1.1 .2012 & standard & 25 & 27 & $2 \%$ \\
\hline
\end{tabular}


Dugová, A.: Changes in the Value Added Tax as the Tool against the Global Crisis.

\begin{tabular}{|c|c|c|c|c|c|}
\hline $\begin{array}{c}\text { Member } \\
\text { state }\end{array}$ & From & \begin{tabular}{|c|} 
Type of \\
VAT rate
\end{tabular} & From & To & $\begin{array}{l}\text { Percentage } \\
\text { points }\end{array}$ \\
\hline \multirow{3}{*}{ Ireland } & 1. 12.2008 & standard & 21 & 21.5 & $0.5 \%$ \\
\hline & 1.1 .2011 & reduced & 4.8 & 9 & $4.2 \%$ \\
\hline & 1.1.2012 & \begin{tabular}{|l|} 
standard \\
\end{tabular} & 21 & 23 & $2 \%$ \\
\hline Italy & 17.9.2011 & standard & 20 & 21 & $1 \%$ \\
\hline \multirow{4}{*}{ Latvia } & 1.1.2009 & reduced & 5 & 10 & $5 \%$ \\
\hline & & standard & 18 & 21 & $3 \%$ \\
\hline & 1.1 .2011 & reduced & 10 & 12 & $2 \%$ \\
\hline & & standard & 21 & 22 & $1 \%$ \\
\hline \multirow{2}{*}{ Lithuania } & 1. 1.2009 & standard & 18 & 19 & $1 \%$ \\
\hline & 1.9.2009 & standard & 19 & 21 & $2 \%$ \\
\hline Malta & 1.1 .2011 & reduced & 5 & 7 & $2 \%$ \\
\hline Netherlands & 1.10.2012 & \begin{tabular}{|l|} 
standard \\
\end{tabular} & 19 & 21 & $2 \%$ \\
\hline \multirow{3}{*}{ Poland } & 1.1 .2011 & reduced & 3 & 5 & $2 \%$ \\
\hline & & reduced & 7 & 8 & $1 \%$ \\
\hline & & standard & 22 & 23 & $1 \%$ \\
\hline \multirow{4}{*}{ Portugal } & 1.7. 2010 & reduced & 5 & 6 & $1 \%$ \\
\hline & & reduced & 12 & 13 & $1 \%$ \\
\hline & & standard & 20 & 21 & $1 \%$ \\
\hline & 1.1 .2011 & \begin{tabular}{|l|} 
standard \\
\end{tabular} & 21 & 23 & $2 \%$ \\
\hline Romania & 1.7.2009 & standard & 19 & 24 & $5 \%$ \\
\hline \multirow{2}{*}{ Slovakia } & 1.1 .2011 & reduced & 6 & 10 & $4 \%$ \\
\hline & & standard & 19 & 20 & $1 \%$ \\
\hline \multirow{4}{*}{ Spain } & 1.7 .2010 & reduced & 7 & 8 & $1 \%$ \\
\hline & & standard & 16 & 18 & $2 \%$ \\
\hline & 1.9 .2012 & reduced & 8 & 10 & $2 \%$ \\
\hline & & standard & 18 & 21 & $3 \%$ \\
\hline \multirow{2}{*}{\begin{tabular}{|l|} 
United \\
Kingdom
\end{tabular}} & 1.1 .2010 & standard & 15 & 17.5 & $2.5 \%$ \\
\hline & 4.1.2011 & standard & 17.5 & 20 & $2.5 \%$ \\
\hline
\end{tabular}

Data source: EC (2013b).

Note: In some countries the new reduced rate was established and some supplies were transferred between the standard and reduced rate.

The increases in VAT rates in many EU member states resulted in higher VAT revenues contributed to the recovery in tax revenues (EC, 2013a). According to the analysis (Kubátová, 2013) of the tax quotas and the tax mixes in OECD countries over the period 2007-2010 it is clear 
that fiscal policy and the behaviour of tax revenues and their structures during the crisis between states are not very similar. Moreover, the changes during the crisis in the level and structure of tax revenues are not typical according to present knowledge of tax theory and policy. These facts might be explained by globalization, which gradually covers national and geographic traditions in the tax area, or the fact that governments respond to the crisis chaotically ad hoc, but after the crisis, the tax system will stabilize again in their old models.

The changes in the position of VAT in the tax mixes of the countries as the consequence of the global economic crisis and the factors of globalization have also the impacts on the position of further taxes (e.g. the direct taxes) in the tax mixes. In comparison the data of years 2008 and 2011 of the EU member states, it is clear that the revenues of the VAT as the percentage of the total taxation increased in $18 \mathrm{EU}$ member states. The revenues of the direct taxes as the percentage of the total taxation decreased in $21 \mathrm{EU}$ member states. The simultaneous increase of the VAT and decrease of the direct taxes can be observed in $14 \mathrm{EU}$ member states. The average in the EU 27 is increasing of the VAT about 0.8 percentage point and the decreasing of the direct taxes about 2 percentage points. The concrete changes are stated in the Table 2: Indirect Taxes as \% of Total Taxation - VAT and Table 3: Direct Taxes as \% of Total Taxation.

Tab. 2: Indirect Taxes as \% of Total Taxation - VAT

\begin{tabular}{|l|c|c|c|c|c|l|}
\hline $\begin{array}{c}\text { Member } \\
\text { state }\end{array}$ & $\mathbf{2 0 0 8}$ & $\mathbf{2 0 0 9}$ & $\mathbf{2 0 1 0}$ & $\mathbf{2 0 1 1}$ & $\begin{array}{c}\text { Difference } \\
\mathbf{2 0 0 8 - 2 0 1 1}\end{array}$ & Difference \\
\hline Austria & 18.2 & 18.9 & 18.9 & 18.5 & 0.4 & increased \\
\hline Belgium & 15.7 & 16.0 & 16.2 & 16.0 & 0.2 & increased \\
\hline Bulgaria & 33.8 & 31.1 & 33.3 & 32.0 & -1.8 & \\
\hline Cyprus & 27.4 & 26.0 & 25.8 & 24.0 & -3.4 & \\
\hline $\begin{array}{l}\text { Czech } \\
\text { Republic }\end{array}$ & 19.7 & 20.6 & 20.7 & 20.4 & 0.8 & increased \\
\hline Denmark & 21.0 & 21.3 & 20.7 & 20.8 & -0.2 & \\
\hline Estonia & 24,9 & 24.8 & 25.7 & 26.0 & 1.1 & increased \\
\hline Finland & 19.5 & 20.2 & 20.1 & 20.6 & 1.1 & increased \\
\hline France & 16.5 & 16.4 & 16.5 & 16.0 & -0.5 & \\
\hline Germany & 18.3 & 19.0 & 19.0 & 18,9 & 0.6 & increased \\
\hline
\end{tabular}


Dugová, A.: Changes in the Value Added Tax as the Tool against the Global Crisis.

\begin{tabular}{|l|c|c|c|c|c|l|}
\hline $\begin{array}{c}\text { Member } \\
\text { state }\end{array}$ & $\mathbf{2 0 0 8}$ & $\mathbf{2 0 0 9}$ & $\mathbf{2 0 1 0}$ & $\mathbf{2 0 1 1}$ & $\begin{array}{c}\text { Difference } \\
\mathbf{2 0 0 8 - 2 0 1 1}\end{array}$ & Difference \\
\hline Greece & 22.7 & 21.1 & 23.2 & 22.3 & -0.5 & \\
\hline Hungary & 19.3 & 21.3 & 23.0 & 23.1 & 3.7 & increased \\
\hline Ireland & 24.5 & 22.7 & 22.7 & 21.3 & -3.3 & \\
\hline Italy & 13,9 & 13.2 & 14.8 & 14.7 & 0.7 & increased \\
\hline Latvia & 23.0 & 22.5 & 24.3 & 24.6 & 1.6 & increased \\
\hline Lithuania & 26.6 & 25.2 & 29.3 & 30.5 & 3.8 & increased \\
\hline Luxembourg & 16.8 & 17.1 & 16.7 & 17.0 & 0.2 & increased \\
\hline Malta & 23.3 & 22.9 & 23.2 & 23.7 & 0.4 & increased \\
\hline Netherlands & 18.5 & 18.3 & 18.7 & 18.0 & -0.5 & \\
\hline Poland & 23.4 & 23.4 & 24.5 & 24.9 & 1.5 & increased \\
\hline Portugal & 25.6 & 22.9 & 24.8 & 25.1 & -0.5 & \\
\hline Romania & 28.2 & 24.7 & 28.6 & 30.8 & 2.6 & increased \\
\hline Slovakia & 23.6 & 23.3 & 22.6 & 23.9 & 0.3 & increased \\
\hline Slovenia & 22.8 & 22.5 & 22.6 & 22.6 & -0.1 & \\
\hline Spain & 15.5 & 13.5 & 17.4 & 17.2 & 1.7 & increased \\
\hline Sweden & 20.0 & 20.7 & 21.3 & 21.3 & 1.3 & increased \\
\hline $\begin{array}{l}\text { United } \\
\text { Kingdom }\end{array}$ & 17.0 & 16.5 & 18.5 & 20.3 & 3.4 & increased \\
\hline EU-27 & 17.6 & 17.4 & 18.3 & 18.4 & 0.8 & increased \\
\hline
\end{tabular}

Data source: EC (2013a).

Tab. 3: Direct Taxes as \% of Total Taxation

\begin{tabular}{|l|c|c|c|c|c|l|}
\hline $\begin{array}{c}\text { Member } \\
\text { state }\end{array}$ & $\mathbf{2 0 0 8}$ & $\mathbf{2 0 0 9}$ & $\mathbf{2 0 1 0}$ & $\mathbf{2 0 1 1}$ & $\begin{array}{c}\text { Difference } \\
\mathbf{2 0 0 8 - 2 0 1 1}\end{array}$ & Difference \\
\hline Austria & 32.9 & 30.1 & 30.3 & 30.9 & -2.0 & decreased \\
\hline Belgium & 38.9 & 36.7 & 37.3 & 38.0 & -0.9 & decreased \\
\hline Bulgaria & 20.6 & 20.3 & 19.5 & 18.9 & -1.7 & decreased \\
\hline Cyprus & 33.5 & 31.8 & 31.1 & 33.3 & -0.2 & decreased \\
\hline $\begin{array}{l}\text { Czech } \\
\text { Republic }\end{array}$ & 23.2 & 21.7 & 20.6 & 21.1 & -2.1 & decreased \\
\hline Denmark & 62.2 & 62.7 & 62.9 & 62.8 & 0.6 & \\
\hline Estonia & 24.7 & 21.2 & 19.8 & 20.0 & -4.7 & decreased \\
\hline Finland & 41.4 & 38.3 & 38.2 & 38.1 & -3.3 & decreased \\
\hline
\end{tabular}




\begin{tabular}{|l|c|c|c|c|c|l|}
\hline $\begin{array}{c}\text { Member } \\
\text { state }\end{array}$ & $\mathbf{2 0 0 8}$ & $\mathbf{2 0 0 9}$ & $\mathbf{2 0 1 0}$ & $\mathbf{2 0 1 1}$ & $\begin{array}{c}\text { Difference } \\
\mathbf{2 0 0 8 - 2 0 1 1}\end{array}$ & Difference \\
\hline France & 27.7 & 24.5 & 25.8 & 26.9 & -0.8 & decreased \\
\hline Germany & 32.0 & 29.8 & 29.3 & 30.0 & -2.0 & decreased \\
\hline Greece & 25.8 & 27.9 & 25.2 & 27.1 & 1.3 & \\
\hline Hungary & 26.3 & 24.9 & 22.6 & 18.7 & -7.6 & decreased \\
\hline Ireland & 39.3 & 38.7 & 38.2 & 43.4 & 4.1 & \\
\hline Italy & 35.7 & 36.0 & 34.8 & 34.7 & -1.0 & decreased \\
\hline Latvia & 33.5 & 27.0 & 27.1 & 26.8 & -6.6 & decreased \\
\hline Lithuania & 31.0 & 20.6 & 17.4 & 17.0 & -14.0 & decreased \\
\hline Luxembourg & 38.0 & 37.7 & 38.7 & 38.0 & 0.0 & \\
\hline Malta & 38.5 & 40.6 & 40.0 & 39.4 & 0.9 & \\
\hline Netherlands & 30.5 & 31.8 & 31.4 & 30.4 & -0.1 & decreased \\
\hline Poland & 25.2 & 23.5 & 21.9 & 21.7 & -3.4 & decreased \\
\hline Portugal & 29.5 & 29.0 & 28.1 & 29.9 & 0.4 & \\
\hline Romania & 24.0 & 24.4 & 22.6 & 21.2 & -2.8 & decreased \\
\hline Slovakia & 22.2 & 19.1 & 19.1 & 19.1 & -3.1 & decreased \\
\hline Slovenia & 24.0 & 22.2 & 21.7 & 21.2 & -2.7 & decreased \\
\hline Spain & 33.8 & 32.8 & 30.8 & 31.6 & -2.2 & decreased \\
\hline Sweden & 42.7 & 42.1 & 42.2 & 42.2 & -0.5 & decreased \\
\hline $\begin{array}{l}\text { United } \\
\text { Kingdom }\end{array}$ & 49.0 & 46.1 & 44.4 & 43.9 & -5.1 & decreased \\
\hline EU-27 & 35.1 & 33.2 & 32.8 & 33.2 & -2.0 & decreased \\
\hline
\end{tabular}

Data source: EC (2013a).

\section{Anti-fraud tools in VAT}

The VAT was massively broadened worldwide after the introduction of VAT in France in the end of 60th years, however, after the initial enthusiasm associated with the concept of transparency and the resistance to the tax evasion, it begun to show that the VAT creates the room for tax evasion (Láchová, 2007). The main types of the frauds in case of VAT are mainly the shadow economy frauds, the suppression frauds, insolvency frauds, Carousel frauds also called missing trader intracommunity frauds, and bogus trader frauds (Harrison - Krelove, 2005; Keen - Smith, 2006). 
Based on the estimation of the European Commission up to EUR 1 trillion yearly is wasted due to the various tax frauds and tax evasion which illegally deprive public budgets. The tax fraud is comprehended as the form of deliberate evasion of tax which is generally punishable under criminal law and the tax evasion generally comprises illegal arrangements where liability to tax is hidden or ignored (EC, 2012a). The significant part of the tax frauds is nowadays committed in VAT area. The amount of money lost can be measured using the VAT gap which is the difference between the VAT really collected and the theoretical VAT liability of all VAT payers if they complied with the law VAT frauds worsen the situation in public budget while states need to cut expenditure and increase revenues (Zídková, 2012). The VAT frauds for the states represents not only the reduction in state revenues but also reduction in the budget of the EU, even generally distorts economic and social environment and also generates revenue that is invested in serious criminal activity. Main tax frauds are committed in VAT field because the imperfect mechanism of the VAT allows creating of fraudulent structures (e.g. missing trader frauds).

The fight against VAT frauds and VAT evasion is in recent years discussed topic in all countries as the states are facing the fiscal difficulties. As the need to fight against VAT frauds is more intensive, the various measures are being increasingly discussed in professional circles. Discussions and the working groups are taking place in global level (e.g. Global Forum, The Tax Policy Group, Fiscalis Programme). In June 2013 the Platform for Tax Good Governance, Aggressive Tax Planning and Double Taxation was established as the further group. However, the concrete steps should be taken as soon as possible instead of further discussions. The recent Green paper about the future of VAT also contains inter alia part regarding VAT frauds and estimation of the VAT gap. Recently states fights against the tax frauds and states have already launched a specific action steps.

For decreasing of the tax frauds and increasing of the tax revenues governments implement various provisions in tax law which are more strict and aggressive and very often leads to more administrative obligations and complications for the VAT payers. Not all provisions are established due to the economic crisis, however, the need to collect money during crisis is higher and therefore some of them were presented recently. The EU and the particular states have already introduced action steps, however, the fight should be much more intensive and coordinated on the global level because the structuring and aggressive tax planning 
of the taxpayers has the global dimension. In a globalized world, with globalizes actors, EU member states would often need more global means to collect taxes due. The EU nowadays enforces indispensable consistent and coherent EU position in the single market and the globalized economy in field of the fight against the VAT frauds although the national measures tax frauds should be also used. On the EU level some framework containing instruments again VAT fraud already exists, however, these instruments need to be reinforced. Therefore, on the end of 2012 the European Commission adopted Action Plan to improve the fight again tax frauds. In December 2012 the European Commission presented an action plan for strengthening the fight against tax fraud which contains various measures including inter alia the introduction of the tax identification number or use of information technology to improve tax collection and exchange of information. On the EU level regarding the VAT fraud the change in the VAT Directive was also proposed. The proposal brings so called "quick reaction mechanism against VAT fraud" because the EU VAT law in force does not provide a legal base for the counteractions of the EU member states wish to take against the VAT frauds. Current treatment is slow and cumbersome in comparison to quickly emerging fraud phenomena at international level. EU Member States may therefore be tempted to take immediate measures without an appropriate legal basis in the EU legislation. The proposal should foresee a procedure in the EU VAT Directive which in very specific situations would provide a legal base for Member States to take immediate measures and this system is called the quick reaction mechanism.

On the other hand, tax frauds signify the risk for taxpayers who must spend money and resources to implement measures stated by the tax law and comply with statutory obligations. For the multinational companies the situation is complicated by the fact that the individual EU member states introduce various measures. Therefore, such measures should be harmonized.

Moreover, the taxpayers face a risk that they get into VAT fraud without even being aware of it which means the additional costs for them or causing damage of the reputation in the market. Taxpayers must therefore implement various preventive measures against tax frauds in business processes such as verification of suppliers or setting of the various provisions in contracts related to fighting against the tax frauds. 
In the EU countries various measures were already introduced especially recently during the years of the global economic crisis. Some of the measures are suggested or discussed. The measures are for instance:

\section{Local reverse charge mechanism}

The reverse charge mechanism for the local transactions protects tax evasion in form of non-paying VAT. Standardly, for local supply between two VAT payers in supply chain the VAT is charged and is not paid to the tax authorities by the supplier, but on the other hand the customer claims the VAT deduction from the same supply. Therefore, state did not collect VAT from suppliers, but on the other hand state returns the VAT deduction to the recipient. If local reverse charge mechanism is applied, the supplier provides the zero rated supply and the VAT is self-assessed by the customer and no VAT evasion can arise. The local reverse charge mechanism was established for businesses where the VAT frauds are very enormous e.g. trade with waste, construction works, trade with the emission credits, electricity, electronic communication services, supply of mobile phones and computer chips, sale and leasing of certain immovable property, sale of particular agricultural products and animals. For future, states should consider the extension of the local reverse charge mechanism also for further business activities or for the transactions in material amounts. The use of the reverse charge mechanism is one of the measures on an optional and temporary basis which was politically agreed by the EU as the way enabling EU member states to better combat VAT fraud (EC, 2012b).

\section{Guarantee of the customer for unpaid VAT}

Another way how to fight against VAT unpaid by the suppliers is the guarantee to pay their VAT liability by the customers. Various states introduced in the VAT acts special provision regarding the guarantee of the customer for unpaid VAT by the supplier. The guarantee is standard securing measure in business law where the guarantee pays the debt or fulfill the obligation if the debtor does not fulfill own obligation and is challenged by the creditor. The guarantee used as the traditional legal instrument used in private business is based on the agreement of the parties, however, the VAT acts presents the guarantee from the law in particular situation. The legal titles for the guarantee stated in the VAT acts are for example following: 
- The customer guarantees unpaid VAT for payments to the bank account if the bank account is held by the service provider outside the country.

- The customer guarantees unpaid VAT if the remuneration for the supply is without the economic justification clearly different from the market usual price.

- The customer guarantees unpaid VAT if he at the moment of the realization knew or should know and could know that the VAT will not be intentionally paid or that the VAT payer will be deliberately unable to pay VAT or that the VAT evasion will be committed (e.g. the tax frauds will be committed).

- The customer guarantees unpaid VAT if he is engaged in the VAT fraud.

- The customer guarantees unpaid VAT if he and supplier are persons connected personally.

- The customer guarantees unpaid VAT if he paid to the unreliable bank account. In the Czech Republic, the public register of reliable bank accounts was established and if customer pays for the purchases to the bank account which is not published in public register then the customer is liable for unpaid VAT. Each VAT payer is therefore obliged to inform the tax authorities on the bank accounts used in business transactions which should be published. On the other hand, customer paying to the supplier should check whether the bank account is published when the customer makes payment order.

- The supplier is at the date of taxable supply unreliable VAT payer. In the Czech Republic the unreliable VAT payers is published in the public register of VAT payers and if the taxable supply is provided by the unreliable VAT payer, the customer is liable for unpaid VAT automatically. The unreliable is VAT payer based on the decision of the tax authorities if the VAT payer breaks the obligation in VAT (e.g. the VAT payer has for 3 months a cumulative VAT underpayment more than CZK 10 million).

- The payments exceeding the given threshold is made in cash instead of the using a bank transfer to identify the receiver of the payment. If the payment is made in cash, the person who pays is reliable for the payment of VAT together with the person who receives the payment. If it is not possible to pay via a bank transfer, the person who pays has the possibility to report the payment to the tax authorities in order to be let off the reliability for the VAT. 
Dugová, A.: Changes in the Value Added Tax as the Tool against the Global Crisis.

\section{Monthly taxable period for majority of VAT payers}

Some states introduced changes in the taxable periods while the majority of VAT payers should be the monthly VAT payers so that the effective control mechanism could be used. Another positive impact for the state budget is also positive cash flow impact because the VAT liabilities are paid in monthly period instead of longer taxable periods (e.g. taxable quarter). The mandatory monthly taxable period is also for new VAT payers for 12 months after the VAT registration.

\section{Financial guarantee obligation in case of VAT registration}

In some countries the new conditions for new VAT payers were introduced. If the new person wants to become the VAT payer, the tax authorities might require as the form of insurance against not paying VAT the financial guarantee which must be paid. Moreover, the further impact for the new VAT payer is that if the VAT payer declares the excess VAT deduction, the money are not returned to the VAT payer for couple of months after the VAT registration and are used for payment of the future VAT liabilities.

\section{Cancellation of the VAT registration}

In some states the tax authorities might decide about the cancellation of the VAT registration of the persons who are noncontact and do not communicate with the tax authorities or do not meet the legal obligations.

\section{E-submission}

Some states require newly to submit all tax fillings solely electronically. Electronic submission of the tax fillings bring to the tax authorities saving in case of the processing, however, in the beginning of the e-submission the initial costs must be spent. But the big advantage of the e-submission is the possibility of effective controlling and matching of the submitted data even on the cross-border level. Therefore e-submission should improve the effective control of the VAT payers.

\section{Rules for input VAT}

In some countries the tax authorities can challenge the input VAT deducted by the VAT payer if the tax authorities can demonstrate that the supplier has committed a VAT fraud (the supplier has charged the VAT and has not paid it) and the purchaser knew or should have known that he was participating to a fraud due to the purchase performed. The refusal 
to deduct the input VAT can be therefore considered. Another form is that the VAT payer is entitled to deduct input VAT only in the case of those supplies where the consideration has been fully paid to the supplier and the customer can prove the payment.

\section{Challenge of the VAT exemption in case of supplies to other EU member states}

In some countries the tax authorities can challenge the VAT exemption of the supplies to other EU member state if the tax authorities can demonstrate that the supplier knew or should have known that the recipient had no actual activity and asses the VAT and penalties additionally.

\section{Tightening of the conditions for risk business}

In some countries the conditions for the specific business (trade with used goods, fuels, bonded warehousing, construction industry) were tightened. For example, the entities are obliged to report the transactions in special tax forms or the specific VAT mechanism as guarantee or local reverse charge is newly applied. In some cases, entities are obliged to register in special register (eg the distributor of the fuel is obliged to register and sell and buying of fuel is possible only between registered persons). Another measure is the separate regulation for fuel sellers who need to submit a security to the tax authority and aim is to prevent situations in which shadow organization not fulfilling the tax liabilities operates in the fuel market.

\section{Reporting of the specific transactions}

In general to prevent the VAT frauds in the transactions between EU member states the reporting in EC Sales Lists was established. At beginning, the supplies of goods to other EU member states were reported and subsequently also the provision of the services according to the general VAT rule is reported. In some countries, the EC Sales Lists are filled only in side of the provider, however, in some countries there are also purchase EC Sales Lists. Another reporting obligation for transactions between EU member states is Intrastat reporting for the persons exceeding given threshold which is administrated by the customs authorities. Moreover, the specific new reporting obligation has been introduced recently. In some countries, the specific reporting is for example on inbound and outbound supplies subject to the local VAT whereby the VAT amount exceeds given threshold. Another reporting is 
connected with the local reverse charge mechanism while the special form is submitted regularly. In this connection, it is the effort of the EU and further organisations on the compatibility of standards for automatic exchange of information on global basis.

\section{The registered cash system}

In some countries the business persons must mandatory issue a cash tickets to his customers for all transactions carried out in the framework of the economic activity. Such measure should improve the possibility of the tax authorities to control the VAT payers.

\section{Tightening of the conditions for establishing of the company}

In some states the necessary condition for starting up of business in no underpayment towards the state. This proceeding means that the new legal entity can be set up only by the person who has no tax arrears.

\section{Specialized financial office establishment}

In many states the specialized financial offices for selected entities and business (financial services industry, VAT groups, the companies with high turnover) were established. From these specialized tax authorities is expected mainly to reduce tax evasion, effective supervision of selected entities and improving the fiscal effect thanks to a dedicated control and sophisticated methods used.

\section{Specialist for VAT frauds in the tax authorities}

In some countries the tax authorities have disposal with the professionals who are trained for detection of the VAT frauds. These specialists analyse the VAT returns, EC Sales List, Intrastat reporting and other fillings and discover the VAT frauds more effectively.

\section{Specialized institutions}

In some countries there is also special institution known as anti-fraud agency. The main goal of the institution is the investigation and governance of the economic, fiscal and financial frauds.

\section{Informing of VAT payers about VAT frauds}

In some countries the tax authorities based on the own analytical activity informs by the official letter the companies that may be in the risk of VAT fraud and are involved in the trade with specific commodities. 


\section{Changes in criminal law regarding tax crimes}

As the tax frauds are committed in recent years also as the organized crime and more frequently, the states have to toughen up the criminal law. The examples of changes in the criminal law are:

- For the tax crime the compulsory penalty prohibition of the business is imposed.

- The length of the penalty of the prison sentence is prolonged especially for the tax made in the significant and large scale or by the organized group.

- The specialized courts in tax crime were set up and also specialized teams of tripartite (tax specialist, investigator, prosecutor) is placed to the serious tax crime investigation.

- Possibility of setting the tax even after the deadline for the tax assessment in case of detection tax fraud was introduced.

- As one of the punishment imposed by the courts is the financial penalties which are more strict.

\section{Imposition of legal liability of legal persons}

Some states already introduced the legal liability of the legal persons. It means that the crime according to the crime code can be committed not only by the individual person by also by the legal entity (e.g. by the limited liability company or by the joint stock company). The tax frauds are serious crimes for which the legal entities are punished for example by the financial penalty of by penalty of abolition of business.

\section{Effective IT solution}

Some countries are gradually developing and introducing new IT solutions which should systematically analyse tax payers and available data. These IT systems should be linked to public registers (eg. central register of motor vehicles or immovable properties) and other internal register of the public authorities. Advanced search and analytics software should offer to the tax authorities monitoring of the transactions and data about the tax payer and based on the scheduled model would asses to the tax payer the appropriate rating. Based on rating could be carried out tax audits. In some countries is even considered to publish the rating of the tax payer. Moreover, the risk VAT payer with poor rating would fall under the strict supervision by the tax authorities. 


\section{VAT cash accounting system introduced}

Also a VAT cash accounting system was introduced as the mandatory system for entrepreneurs with given turnover. VAT payer must collect and pay VAT to supplies of goods and services when they cash and customer has the right to VAT deduction only if customer can proof that the invoice was paid.

\section{Other measures}

Also in some countries were established further partial measures, for example following:

- The tax authorities have broader possibilities to access private property.

- On the building sites the companies have to put up a sign telling what the company is performing work on the building.

- The company cars have to be marked with the company's registration number.

\section{Conclusion}

This paper pointed out that in recent years there has been very intensive changes in the VAT field made by the EU member states. Most states have responded to the global economic crisis by increasing in VAT rates and the obvious trend in the EU is the increase of the VAT rates. The increase of the revenues of the VAT influenced also the composition of the tax mixes of the EU member states. Among other, it can be observed that the states which increased the revenues in the VAT simultaneously decreased the direct taxes. During the crisis years the changes in taxation were different than tracked by the tax policy in the past. This is primary due to ad hoc changes in taxation and the factors of globalisation.

Moreover, states started with fight against the tax frauds and tax evasion of VAT rapidly. States introduced several measures to fight against VAT frauds in their national legislation. However, as current economy is globalized the global action steps should be taken on the EU level as well as on the global level. The EU currently focuses on the quick reaction mechanism and application of the local reverse charge mechanism (EC, 2012c). It is also considered the future of the existence of the VAT.

Based on the active steps and proposed planes prepared by the EU and further global players it is clear that the fight against the tax frauds is currently the prominence. However, the concrete steps and efforts at 
national level, EU, G8, G20, OECD and global level should be taken as soon as possible instead of further discussions. However, the tax payers should expect in future pressure on the discovering the tax frauds using the sophisticated methods of the tax authorities and the international exchange of information.

\section{References:}

[1] Buus, T. (2012): Daně z př́ijmů versus daň z pridané hodnoty v malé otevřené ekonomice. Politická ekonomie, 2012, roč. 60, č. 1, s. 58-80.

[2] Copenhagen Economics (2007): Study on Reduced VAT Applied to Goods and Services in the Member States of the EU. [on-line], Taxation Papers 13, c2007, [cited $14^{\text {th }}$ July, 2013], $<$ http://ec.europa.eu/taxation_customs/resources/documents/taxation/ vat/how_vat_works/rates/study_reduced_vat.pdf $>$.

[3] Dušek, L. - Jánský, P. (2011): Jak by sjednocení DPH na 17.5\% dopadlo na domácnosti a veřejné rozpočty. [on-line], Praha, Národohospodářský ústav AVČR, c2011, [cited 14 ${ }^{\text {th }}$ July, 2013], <http://idea.cerge-ei.cz/documents/iphp_201102.pdf>.

[4] EC (2012a): Communication from the Commission to the European Parliament and the Council on Concrete Ways to Reinforce the Fight against Tax Fraud and Tax Evasion including in Relation to Third Countries. [on-line], Brussels, European Commission, c2012, [cited $14^{\text {th }}$ July, 2013],

$<$ http://ec.europa.eu/taxation_customs/resources/documents/common /publications/com_reports/taxation/com(2012)351_en.pdf >.

[5] EC (2012b): Communication from the Commission to the European Parliament and the Council an Action Plan to Strengthen the Fight against Tax Fraud and Tax Evasion. [on-line], Brussels, European Commission, c2012, [cited $14^{\text {th }}$ July, 2013], $<$ http://ec.europa.eu/taxation_customs/resources/documents/taxation/ tax_fraud_evasion/com_2012_722_en.pdf >.

[6] EC (2012c): Proposal for a Council Directive Amending Directive 2006/112/EC on the Common System of Value Added Tax as Regards a Quick Reaction Mechanism against VAT Fraud. [on-line], Brussels, European Commission, c2012, [cited $14^{\text {th }}$ July, 2013], $<$ http://ec.europa.eu/taxation_customs/resources/documents/taxation/ vat/key_documents/legislation_proposed/com(2012)428_en.pdf>. 
Dugová, A.: Changes in the Value Added Tax as the Tool against the Global Crisis.

[7] EC (2013a): Taxation Trends in the EU. [on-line], Brussels, European Commission, c2013, [cited $14^{\text {th }}$ July, 2013], $<$ http://ec.europa.eu/taxation_customs/taxation/gen_info/economic_a nalysis/tax_structures/index_en.htm>.

[8] EC (2013b): VAT Rates Applied in the Member States of the EU. [on-line], Brussels, European Commission, c2013, [cited $14^{\text {th }}$ July, 2013], $<$ http://ec.europa.eu/taxation_customs/resources/documents/taxation/ vat/how_vat_works/rates/vat_rates_en.pdf $>$.

[9] Gordon, R. H. - Nielsen, S. B. (1997): Tax Evasion in an Open Economy: Value-added vs. Income Taxation. Journal of Public Economics, 1997, vol. 66, no. 2, pp. 173-197.

[10] Harrison, G. - Krelove, R. (2005): VAT Refunds: A Review of Country Experience. [on-line], Washington, D. C. International Monetary Fund Working Paper 05/218, c2005, [cited $14^{\text {th }}$ July, 2013], <http://www.imf.org/external/pubs/ft/wp/2005/wp05218.pdf>.

[11] Keen, M. - Smith, S. (2006): VAT Fraud and Evasion: What Do We Know and What Can Be Done? National Tax Journal, 2006, vol. 59, no. 4, pp. 861-887.

[12] Kubátová, K. (2010): Daňová teorie a politika. Praha, Wolters Kluwer, 2010.

[13] Kubátová, K. (2013): Vliv krize na výši a strukturu daňových výnosů zemí OECD podle regionü. Littera Scripta, 2013, vol. 6, no. 1, pp. 5160.

[14] Láchová, L. (2007): Daňové systémy v globálním světě. Praha, ASPI, 2007.

[15] OECD (2013): OECD Economic Surveys: Italy 2013 - Assessment and recommendations. [on-line], Paris, Organisation for Economic Co-operation and Development, 2013, [cited 14 $4^{\text {th }}$ July, 2013], <http://dx.doi.org/10.1787/eco_surveys-ita-2013-en>.

[16] Zídková, H. (2012): Diskuse k metodám odhadi̊ stínové ekonomiky. Acta Oeconomia Pragensia, 2012, vol. 20, no. 6, pp. 3-17. 


\title{
Changes in the Value Added Tax as the Tool against the Global Crisis
}

\author{
Alena DUGOVÁ
}

\begin{abstract}
As a result of the global economic crisis the governments of the states has been forced to present various proceedings especially in field of taxation to maintain or increase the tax revenues and to safe economy.

Majority of the states decided to make changes inter alia in indirect taxation as the tool against the crisis. Some of the actions planned the short term effects and some of them are rather as the long term arrangement to fight against crisis. The states usually increased the VAT rates to maintain or increase the public revenues. However, states also launched the proceedings against the tax frauds especially in VAT area where the tax frauds are very frequent.

Results of this research might be useful as the inspiration for other states in the global economy.
\end{abstract}

Key words: VAT rates; Tax frauds; Anti-fraud tool.

JEL classification: H26, H200. 